\title{
Parasites of Three Closely Related Antarctic Fish Species (Teleostei: Nototheniinae) from Elephant Island
}

\author{
Katharina G. Alt ${ }^{1}$ (D) Sarah Cunze ${ }^{1} \cdot$ Judith Kochmann ${ }^{2} \cdot$ Sven Klimpel $^{1,2}$
}

Received: 25 January 2021 / Accepted: 6 July 2021 / Published online: 17 July 2021

(c) The Author(s) 2021

\begin{abstract}
Background Studies of parasite communities and patterns in the Antarctic are an important knowledge base with the potential to track shifts in ecological relations and study the effects of climate change on host-parasite systems. Endemic Nototheniinae is the dominant fish group found in Antarctic marine habitats. Through their intermediate position within the food web, Nototheniinae link lower to higher trophic levels and thereby also form an important component of parasite life cycles. The study was set out to gain insight into the parasite fauna of Nototheniops larseni, N. nudifrons and Lepidonotothen squamifrons (Nototheniinae) from Elephant Island (Antarctica).

Methods Sampling was conducted at three locations around Elephant Island during the ANT-XXVIII/4 expedition of the research vessel Polarstern. The parasite fauna of three Nototheniine species was analysed, and findings were compared to previous parasitological and ecological research collated from a literature review.

Results All host species shared the parasites Neolebouria antarctica (Digenea), Corynosoma bullosum (Acanthocephala) and Pseudoterranova decipiens E (Nematoda). Other parasite taxa were exclusive to one host species in this study. Nototheniops nudifrons was infected by Ascarophis nototheniae (Nematoda), occasional infections of $N$. larseni with Echinorhynchus petrotschenkoi (Acanthocephala) and L. squamifrons with Elytrophalloides oatesi (Digenea) and larval tetraphyllidean Cestoda were detected.

Conclusion All examined fish species' parasites were predominantly euryxenous regarding their fish hosts. The infection of Lepidonotothen squamifrons with Lepidapedon garrardi (Digenea) and Nototheniops larseni with Echinorhynchus petrotschenkoi represent new host records. Despite the challenges and limited opportunities for fishing in remote areas, future studies should continue sampling on a more regular basis and include a larger number of fish species and sampling sites within different habitats.
\end{abstract}

Keywords Demersal fish $\cdot$ Marine food webs $\cdot$ Antarctic parasites $\cdot$ Southern Ocean

\section{Introduction}

The Antarctic Circumpolar Current (ACC) which forms the boundaries of the Southern Ocean is the biggest physiothermal barrier found in the world oceans $[1,2]$. With its strong eastward current and thermohaline frontal systems it serves as a natural boundary for most organisms inhabiting

Katharina G. Alt

alt@bio.uni-frankfurt.de

1 Institute for Ecology, Evolution and Diversity, Goethe University, 60438 Frankfurt am Main, Germany

2 Senckenberg Biodiversity and Climate Research Centre, Senckenberg Gesellschaft für Naturforschung, 60325 Frankfurt am Main, Germany the Southern Ocean which promoted a high degree of endemism and adaptation to the distinctive features of this cold environment [3].

The Antarctic Peninsula (AP) extends from the Antarctic continent towards the southern extension of South America (Cape Horn, Chile), and is connected by the Drake Passage and the Polar Front found between $56.8^{\circ} \mathrm{S}$ and 59.3 ${ }^{\circ} \mathrm{S}$ [4]. The area around Elephant Island (South Shetland Islands) is characterised by its high net production as one of the nursery areas of the keystone species Antarctic krill (Euphausia superba DANA, 1850), the region's most important energy resource [5-9]. It belongs to the seasonal pack ice zone, which is defined by not being covered by an ice sheet perennially. As a result, the region has a different habitat structure compared to high Antarctic areas (from $70^{\circ}$ South), such 
as a steep shelf slope, lack of littoral, vast depth range, and unique marine fauna [10]. Average temperatures at the western AP have increased during the last years of proceeding climate change and reached the maximum measured temperature of $18.4^{\circ} \mathrm{C}$, February 6th 2020, measured at Esperanza research base $[11,12]$ (World Meteorological Organization 2020). The resulting decrease in sea ice is expected to severely impact the local ecosystem [5]. Since krill depends on ice algae as their winter food, the decrease of ice could lead to a shift in the communities of pelagic feeders and all dependent organisms [5].

Inshore fish are an essential link for the energy flow between invertebrates and higher predators. They are mostly consumers of benthos and zooplankton and prey of predatory mammals and birds, which promotes energy transport from sea to land. In offshore regions, fish forage on nekton and zooplankton and are preyed on by larger fish, because they are out of reach for most seals and birds [13]. Despite krill being the most important factor for energy flow in offshore habitats of the Southern Ocean, demersal fish seem to be more important in inshore habitats than krill [13].

The Notothenioidea are the most dominant fish group found in the Southern Ocean and the paragon of the adaptive radiation of teleosts in the marine environment [14]. The Nototheniidae have evolved from strictly benthic ancestors characterised by the lack of a swim bladder. Important features shared by all Nototheniidae are slow ontogenesis and long generation time $[2,10,15]$. Throughout their radiation and diversification, some species have evolved to follow a benthopelagic lifestyle. The 16 nototheniid species occurring outside the Southern Ocean [16] are all adapted to a benthic habitat and possess a different parasite fauna than Antarctic Nototheniidae [16-20]. The subfamily Nototheniinae exclusively occurs in the Southern Ocean [17]. Nototheniops larseni (LÖNNBERG, 1905), N. nudifrons (LÖNNBERG, 1905) and Lepidonotothen squamifrons (GüNTHER, 1880; syn. L. kempi) are among the most abundant fish species of the West Antarctic Peninsula and Southern Scotia Arc $[13,21,22]$. They are distinguished by their depth ranges and habitats which results in Nototheniops nudifrons being more abundant inshore (e.g. fjords), N. larseni (also occurs inshore) and $L$. squamifrons (exclusively found at the outer shelf) being more common in offshore areas [13]. With their intermediate position within the food web, these species create an important link for energy flow from lower to higher trophic levels and play an important part in the life cycles of parasites.

The diversity and abundance of parasite infection in a host are, among other factors (i.e. host age/size), connected to the variability and trophic level of its diet. Infection rates of zooplankton and macroinvertebrates with helminth parasite stages are lower than the parasite prevalence in small fish [23-25]. By including higher trophic level organisms into its diet, a host is more likely to acquire parasites from its food. But parasites can also be used as an indicator of diet components of their hosts in addition to stomach content analysis, which can only represent the diet at the time of sampling. If the parasites' life cycles are known, infection patterns can provide information about the higher trophic levels and potential predators of their hosts.

The fundamental research in the field of Antarctic parasitology (notably K. Zdizitowiecki and colleagues) has provided a knowledge base to track the shift of ecological relations in an ecosystem eminently affected by increasing temperatures. However, early studies have mostly focused on parasite species descriptions, identification keys, and life cycles of certain taxa [26-29], while studies on the parasite communities of the fishes examined [30, 31] are more scarce. In this study, we aim to contribute to the monitoring of marine communities from the seasonal pack ice zone off Elephant Island. Based on parasitological data, collected during an expedition of the RV Polarstern, and a literature review we intend to gain insight into the ecology of three fish species of the subfamily Nototheniinae, Nototheniops larseni, $N$. nudifrons and Lepidonotothen squamifrons, more specifically their diet, potential predators and their position in the food web.

\section{Materials and Methods}

\section{Sampling}

Host sampling of Nototheniidae, Nototheniops larseni $(n=40), N$. nudifrons $(n=40)$ and Lepidonotothen squamifrons $(n=49)$, was conducted at the ANT-XXVIII/4 expedition of the RV Polarstern to the Antarctic Peninsula (CCAMLR Subarea 48.1), from March 13th to April 9th, 2012. Specific sampling locations were situated around Elephant Island (Fig. 1, Table S1). Fishing was performed through bottom trawling. The catch was sorted, identified, measured, weighted and fish samples were stored at $-20^{\circ} \mathrm{C}$ until further examination.

\section{Host and Parasite Taxonomy}

Despite contradictory database entries about the taxonomic status of the fishes examined in this study (the online platforms FishBase [32] and World Register of Marine Species [33] assign the genus Lindbergichthys) this study follows Eschmeyer's Catalog of Fishes [34] referring to the taxonomy proposed by Near et al. [35], assigning the genus Nototheniops to both $N$. larseni and $N$. nudifrons. The taxonomy of Lepidonotothen squamifrons follows the findings of Miya et al. [36]. All references 
Fig. 1 Sampling locations of bottom trawl fisheries around Elephant Island. Haul 188=red, haul $190=$ blue, haul $206=$ yellow. (Projection: South Pole Lambert Azimuthal Equal Area, WKID: Authority: 102020 (Esri), Geographic Coordinate System: GCS_WGS_1984.) (colour figure online)

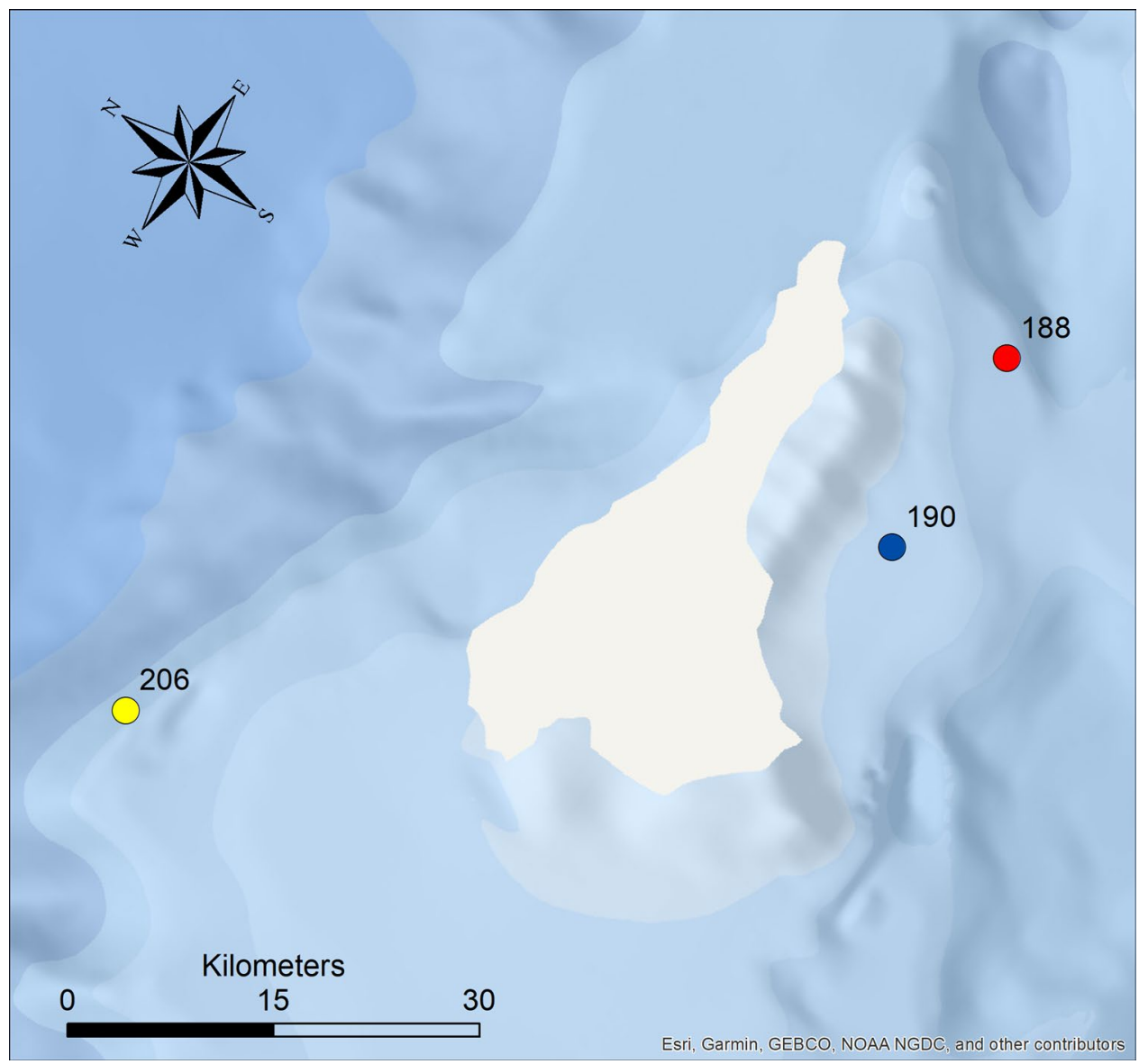

agree on the placement of $L$. squamifrons, $N$. larseni and $N$. nudifrons into the subfamily Nototheniinae.

Since the parasitological findings from this study need to be put into the context of previous research, a list of the recorded parasites of Nototheniops larseni, $N$. nudifrons and Lepidonotothen squamifrons, was compiled. This was based on the checklist of Antarctic fish parasites by Oğuz et al. [37] complemented by the entries in the host-parasite database of the Natural History Museum London [38] and search on Google Scholar. The changes of host taxonomy were taken into account by including the known synonyms: Notothenia larseni, Lepidonotothen larseni for Nototheniops larseni; Notothenia nudifrons, Lepidonotothen nudifrons, Lindbergichthtys nudifrons, Notothenia mizops nudifrons for Nototheniops nudifrons and Notothenia squamifrons, Lepidonotothen kempi, Notothenia brevipectoralis, Notothenia kempi, Notothenia macrophthalma for Lepidonotothen squamifrons. Outdated systematics of parasite records were revised to recent taxonomic classification using the World Register of Marine Species [33]. Despite their careful assembly, the lists might not be fully exhaustive. The findings were visualised as bipartite networks using $\mathrm{R}$ version 4.0.3, following a script by Brandl et al. [39].

\section{Host Morphometry and Diet}

The fish samples were thawed at room temperature and morphometric measures were taken. The diet of the fishes was examined by analysing the stomach contents. Full and empty stomach weight was determined, and each food item was identified to the lowest possible taxonomic level. The different food organisms were counted and weighted. Trophic measures were calculated according to Hyslop [40].

\section{Parasitological Examination}

The host fishes were examined for metazoan ecto- and endoparasites, using a stereomicroscope (Olympus SZ61) with transmitting light (Olympus KL1600 LED, Olympus Corporation). The body surface and buccal and nasal cavities were examined for ectoparasites, and the visceral cavity, organs, and alimentary tract were examined for endoparasites. Parasites were washed in saline solution or purified water (Acanthocephala), determined taxonomically, and counted. Parasitological parameters were calculated as stated in Bush et al. [41].

Parasite species were identified either by their morphological (Digenea, Cestoda and Acanthocephala) or molecular 
characteristics (Nematoda). For morphological identification, specimens were treated with 4\% Roti-Histofix (Roth) and mounted on microscope slides in glycerine. The respective keys by Zdzitowiecki $[42,43]$ were used. Pictures were taken with an Olympus BX53 microscope and cellSens Standard software version 1.14 (Olympus Corporation). Specimens of the identified parasites were deposited in the scientific collection of the Senckenberg Research Institute and Natural History Museum, Frankfurt am Main, Germany, Catalogue Number SMF 15198 (Elytrophalloides oatesi), 15,199 (Lepidapedon garrardi), 15200 (Neolebouria antarctica), 17065 (Corynosoma bullosum) and 17066 (Echinorhynchus petrotschenkoi).

Nematodes were identified genetically because larval stages often lack distinct morphological features. Due to the high number of Nematoda infecting each host species, a subsample was taken to reduce sequencing costs. A random sub-sample was taken from the morphologically pre-sorted samples for molecular species determination. For this reason, the calculation of parasitological parameters according to Bush et al. [41] was omitted in the case of Nematoda.

Anisakidae were distinguished using internal transcribed spacers (ITS-1, $5.8 \mathrm{~s}$, ITS-2) as described Zhu et al., Shih and Klimpel et al. [44-47], using primers NC5 and NC2. For Cystidiocolidae specimens primers flanking the ribosomal small subunit (SSU) were designed using Geneious 8.17 software (f 93 5'-CCA ACG TGG ATA ACT GTG GT-3'; r 880 5'-CTC TCA CGC AGC GAT ACG AA-3'). The PCR was performed in 30 cycles with $60 \mathrm{~s}$ initiation at $95^{\circ} \mathrm{C}, 30$ cycles of $45 \mathrm{~s}$ denaturation at $94{ }^{\circ} \mathrm{C}, 45 \mathrm{~s}$ hybridisation at $52{ }^{\circ} \mathrm{C}$, 45 s elongation at $72{ }^{\circ} \mathrm{C}$ and a 10 min final extension at $72{ }^{\circ} \mathrm{C}$. Sanger sequencing was performed at Seqlab (Göttingen). A multiple alignment with sequences deposited in NCBI Genbank was performed using nBLAST [48]. Sequencing data are given in the supplemental information (Data S1).

\section{Results}

\section{Host Diet}

The digestion stage of the stomach contents of the three fish species varied. While there was mostly mucus detected in the stomachs of Nototheniops larseni and L. nudifrons, most food items of $L$. squamifrons were assigned to a taxonomic group (Table S2).

The sample of $N$. larseni $(n=40)$ included 18 stomachs with defined contents. The prey predominantly consisted of Crustacea (IRI $=18,041)$. Euphausiacea were identified as a food item and one specimen had preyed on fish.

The stomach contents of most samples of $N$. nudifrons $(n=40)$ were undefined. The contents of 7 stomachs could be assigned to a taxon, the rest contained undefined mucus. Based on these limited findings, Crustacea (IRI $=6409)$ were the most important food item of $N$. nudifrons, followed by benthic Mollusca ( $I R I=3590$ ).

Almost all food items of $L$. squamifrons $(n=49)$ could be identified. The most important group was Crustacea (IRI $=13,379, F=97.62 \%$ ), where Amphipoda and Euphausiacea were the most frequent (both taxa with $F=59.52 \%$ ). Other rarer food items of $L$. squamifrons were Isopoda, Ostracoda, Mollusca (Gastropoda and Bivalvia), Polychaeta and Teleostei.

\section{Parasite Fauna}

The parasite fauna of the three Nototheniinae spp. included the taxa Digenea, Acanthocephala, Cestoda and Nematoda. The three host species shared several parasites with different prevalences and intensities (Table 1). The digenean Neolebouria antarctica (SZIDAT \& GRAEFE, 1967; ZDZITOWIECKI, 1990), the acanthocephalan Corynosoma bullosum (LiNstow, 1892; RaIlliet \& Henry 1907) and nematode Pseudoterranova decipiens $\mathrm{E}$ were detected in all host species. Photographs of the parasites are shown in Fig. 2.

Digenea were isolated from the alimentary tract of the host specimens. Three different species were identified in Lepidonothothen squamifrons, Neolebouria antarctica, Lepidapedon garrardi (LeIPER \& AtKInSON, 1914; MANTER, 1926) and Elytrophalloides oatesi (LEIPER \& ATKINSON, 1914; SZIDAT \& GRAEFE, 1967). Lepidonotothen squamifrons had the highest prevalence and diversity of Digenea. The specimens of Nototheniops nudifrons were infected with at least two different digenean species, Neolebouria antarctica and Lepidapedon garrardi. The lowest number of digeneans were isolated from Nototheniops larseni. Here, Neolebouria antarctica was identified as well.

Nematoda was the taxon with the highest prevalence and intensities in all host species. Nematodes were identified in all samples of Nototheniops nudifrons and L. squamifrons. Nototheniops larseni was the host with the highest infection intensity, one specimen was infected with 52 nematodes. The subsample of nematodes used for molecular barcoding revealed an infection with $P$. decipiens $\mathrm{E}$ and Contracaecum osculatum s.l. in all three host species (Table 2). Ascarophis nototheniae (JoHNSTON \& MAwson, 1945) was exclusively detected in the stomach of $N$. nudifrons. Contracaecum osculatum $\mathrm{D}$ was identified in $L$. squamifrons.

Cestoda only occurred in one host species. Unidentified tetraphyllidean larvae were isolated from two host specimens of $L$. squamifrons.

Acanthocephala were the second most frequent parasite taxon in all hosts, preceded by the Nematoda. Nototheniops nudifrons had the highest prevalence, followed by L. squamifrons and $N$. larseni. The parasites occurred as 
Table 1 Parasites of

Nototheniops larseni, $N$. nudifrons and Lepidonotothen squamifrons from the SSI

\begin{tabular}{|c|c|c|c|c|c|c|}
\hline Host & Parasite & $n$ & $P[\%]$ & $I$ & $\mathrm{mI}$ & $\mathrm{mA}$ \\
\hline \multirow{10}{*}{$\begin{array}{l}\text { Nototheniops larseni } \\
(n=40)\end{array}$} & Digenea & 5 & 5 & $1-2$ & 2.5 & 0.125 \\
\hline & Digenea indet & 3 & 5 & $1-2$ & 1.5 & 0.075 \\
\hline & Neolebouria antarctica & 2 & 2.5 & 2 & 2 & 0.05 \\
\hline & Nematoda & 499 & 97.5 & $1-52$ & 12.79 & 12.48 \\
\hline & Acanthocephala & 49 & 60 & $1-6$ & 2.04 & 1.225 \\
\hline & Acanthocephala indet & 1 & 2.5 & 1 & 1 & 0.025 \\
\hline & Corynosoma spp. & 27 & 42.5 & $1-5$ & 1.59 & 0.675 \\
\hline & C. bullosum & 6 & 15 & 1 & 1 & 0.15 \\
\hline & Echinorhynchus petrotschenkoi & 4 & 7.5 & $1-2$ & 1.33 & 0.1 \\
\hline & Metacanthocephalus spp. & 11 & 15 & $1-6$ & 1.83 & 0.275 \\
\hline \multirow{10}{*}{$\begin{array}{l}\text { Nototheniops nudifrons } \\
(n=40)\end{array}$} & Digenea & 11 & 7.5 & $1-4$ & 3.67 & 0.275 \\
\hline & Digenea indet & 5 & 5 & $2-3$ & 2.5 & 0.125 \\
\hline & Lepidapedon garrardi & 1 & 5 & 1 & 1 & 0.05 \\
\hline & Neolebouria antarctica & 4 & 2.5 & 4 & 4 & 0.1 \\
\hline & $\underline{\text { Nematoda }}$ & 503 & 100 & $1-38$ & 12.58 & 12.58 \\
\hline & Acanthocephala & 226 & 90 & $1-34$ & 6.28 & 5.65 \\
\hline & Acanthocephala indet & 51 & 50 & $1-7$ & 2.55 & 1.275 \\
\hline & Corynosoma spp. & 10 & 12.5 & $1-4$ & 2 & 0.25 \\
\hline & C. bullosum & 1 & 2.5 & 1 & 1 & 0.025 \\
\hline & Metacanthocephalus spp. & 164 & 82.5 & $1-34$ & 4.97 & 4.1 \\
\hline \multirow{12}{*}{$\begin{array}{l}\text { Lepidonotothen squamifrons } \\
(n=49)\end{array}$} & Digenea & 78 & 59.2 & $1-11$ & 2.69 & 1.591 \\
\hline & Digenea indet & 50 & 40.8 & $1-11$ & 2.5 & 1.02 \\
\hline & Elytrophalloides oatesi & 1 & 2.04 & 1 & 1 & 0.02 \\
\hline & Lepidapedon garrardi & 17 & 16.3 & $1-6$ & 2.13 & 0.346 \\
\hline & Neolebouria antarctica & 10 & 14.3 & $1-34$ & 1.43 & 0.204 \\
\hline & $\underline{\text { Nematoda }}$ & 437 & 100 & $1-36$ & 8.92 & 8.92 \\
\hline & $\underline{\text { Cestoda }}$ & 8 & 4.08 & $2-6$ & 4 & 0.163 \\
\hline & Acanthocephala & 298 & 89.8 & $1-19$ & 6.77 & 6.081 \\
\hline & Acanthocephala indet & 19 & 22.4 & $1-3$ & 1.72 & 0.387 \\
\hline & Corynosoma spp. & 142 & 73.5 & $1-19$ & 3.94 & 2.897 \\
\hline & C. bullosum & 127 & 73.5 & $1-10$ & 3.53 & 2.591 \\
\hline & Metacanthocephalus spp. & 10 & 16.3 & $1-3$ & 1.25 & 0.204 \\
\hline
\end{tabular}

Quantity $=n$, Prevalence $=P[\%]$, (mean) Intensity $=(\mathrm{m}) \mathrm{I}$, mean Abundace $=\mathrm{mA}$

Taxon groups are underlined to better distinguish the parasitological parameters of the whole group fromparasitological parameters of specimens that were not identified to a more specific taxon adults (Echinorhynchus petrotschenkoi (RoDJUK, 1984, ZDZITOWIECKI, 1989) and Metacanthocephalus spp.) or cystacanth stages (Corynosoma spp.).

Each fish species had some parasites that were either exclusive in the sample or occurred more frequently than in the other host species, especially from the group Acanthocephala. With an infection of Echinorhynchus petrotschenkoi in the stomach, $N$. larseni was the only host species infected by this parasite. Nototheniops nudifrons had the highest prevalence and infection intensities by the genus Metacanthocephalus, which occurred in the pyloric caeca and intestine. The highest prevalence of Corynosoma bullosum was detected in L. squamifrons.
Parasite records of Nototheniops larseni, N. nudifrons and Lepidonotothen squamifrons and host spectrum of the identified parasites collated from literature are presented in Figs. 3 and 4, references of the records are stated in Tables S3 and S4.

\section{Discussion}

Prey organisms can vary with the habitat of the fish and determine which parasites they ingest through their diet. Both the life cycles and infestation patterns of the parasites are used to gain insight into the ecology of the fish studied. 
Fig. 2 Parasites of notothenioid fishes from Elephant Island. A Elytrophalloides oatesi,

B Lepidapedon garrardi, $\mathbf{C}$ Neolebouria antarctica, $\mathbf{D}$

Cestode cercoid with bilocular acetabula, E Echinorhynchus petrotschenkoi, $\mathbf{F}$ Corynosoma bullosum (colour figure online)

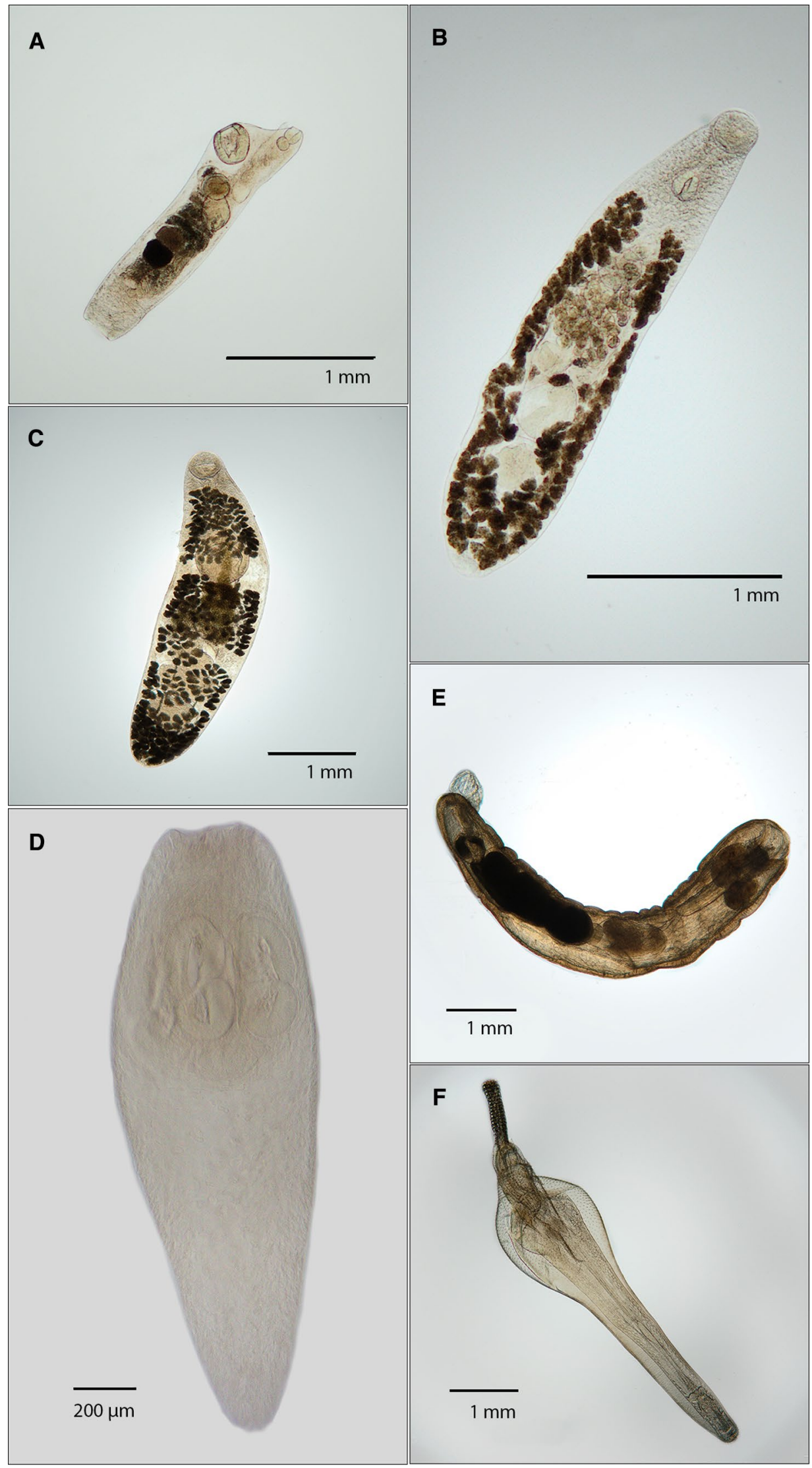


Table 2 Nematoda subsamples from Nototheniops larseni, N. nudifrons and Lepidonotothen squamifrons, stating number of hosts, number of parasites and NCBI-Accession numbers (Ref. ID)

\begin{tabular}{|c|c|c|c|c|c|c|c|c|}
\hline \multirow[t]{2}{*}{ Host } & \multicolumn{2}{|c|}{$\begin{array}{l}\text { Ascarophis noto- } \\
\text { theniae }\end{array}$} & \multicolumn{2}{|c|}{$\begin{array}{l}\text { Contracaecum } \\
\text { osculatum s.1 }\end{array}$} & \multicolumn{2}{|c|}{ Contraceacum osculatum D } & \multicolumn{2}{|c|}{ Pseudoterranova decipiens $\mathrm{E}$} \\
\hline & $n$ & Ref. ID & $n$ & Ref. ID & $n$ & Ref. ID & $n$ & Ref. ID \\
\hline Nototheniops larseni $(n=27)$ & - & - & - & - & 7 & KY275507.1, MG787548.1 & 27 & $\begin{array}{l}\text { KF017610.1, KX378173.1, } \\
\text { KX378174.1 }\end{array}$ \\
\hline Nototheniops nudifrons $(n=20)$ & 13 & DQ094172.1 & 3 & KY275507.1 & - & - & 6 & KX378173.1, KX378174.1 \\
\hline $\begin{array}{l}\text { Lepidonotothen squamifrons } \\
\quad(n=19)\end{array}$ & - & - & 5 & MT258528.1 & 2 & KY275507.1, MG787549.1 & 12 & $\begin{array}{l}\text { KF017610.1, KX378173.1, } \\
\text { KX378174.1 }\end{array}$ \\
\hline
\end{tabular}

We here discuss aspects of diet and parasitisation patterns of Antarctic fish (Nototheniinae), focusing on the three species, Nototheniops larseni, $N$. nudifrons and Lepidonotothen squamifrons and the results gained through our sampling and a current literature review.

\section{Diet}

Dietary analyses depend on the food consumed directly before and digestion degree at the point of sampling. Indigestible components, bones, exoskeletons, shells, bristles, etc., can be used for morphological identification. Fish from the same size group caught in a single haul usually contain similar food items and digestion stages.

In this study, the stomach contents of Nototheniops larseni and $N$. nudifrons were in an advanced digestion stage, which resulted in a low sample and statistically unreliable calculations of dietary parameters, overestimating proportions and importance of food components. However, the few food items identified did not contradict previous findings.

Stomach contents of $N$. larseni were mostly identified as Euphausiacea and Teleostei (rare). These findings agree with the reported main food source of $N$. larseni being krill (Euphausia superba), amphipods (Probolisca ovata, Gitanopsis squamosa, Oradarea bidentata, Prostebbingia gracilis, P. brevicornis, Paramoera spp.) and copepods [49-51]. The food composition (krill, hyperiids, copepods, young fish), reports of benthic amphipoda and stones in the stomach of $N$. larseni indicate an epibenthic lifestyle [13, 51]. A positive connection between fish size and increasing consumption of Mysida (e.g. Antarctomysis maxima) and hyperiid Amphipoda (Parathemisto gaudichaudii) has been observed [50].

The discovered food items of $N$. nudifrons from this study point to a benthic feeding strategy, agreeing with previous research [13]. Other studies described the diet composition of $N$. nudifrons as a typical secondary consumer with an increasing number of different prey taxa with increasing total length [52, 53]. Previous research suggests an ontogenetic shift of the diet from cyclopoid and calanoid copepods (e.g. Paraeuchaeta antarctica and Pleuromamma. gracilis) and Mysida to benthic invertebrates, amphipods, polychaetes and isopods, but also krill (E. superba), and shrimp (Crangon antarcticus, Chorismus antarcticus) [13, 50, 52, 54, 55].

A variation of food components at different sites has been described for $N$. larseni and $N$. nudifrons, adapting to the availability of food items, related to the respective habitat conditions [52, 56-60].

The stomach contents of L. squamifrons were preserved best in this study, hence the highest diversity of food items. The higher variety of food organisms in adult specimens compared to subadult samples of L. squamifrons from this study indicate a size and maturity-related ontogenetic shift in feeding behaviour, as previously observed in other Nototheniinae [52]. Other studies found the diet of L. squamifrons to be similar to $N$. larseni [61]. Both fishes feed predominantly on krill, with a lower proportion of benthic invertebrates and L. squamifrons also feed on fish [61]. The reported feeding behaviour of L. squamifrons includes demersal and pelagic hunting [13]. Salps have been reported to be a component of L. squamifrons diet [13], which could be advantageous in the light of a growing salp population due to the increase of water temperatures [5, 62-64].

Krill is a dominant diet component of demersal fish summer diet at the South Shetland Islands region, and its biomass is positively correlated with demersal fish abundance. The reported distribution of krill in the water column reaches the bottom, which agrees with a demersal lifestyle of krill consuming fish species [61, 65-68]. The proportion of Amphipoda and krill in the demersal fish diet varies seasonally, more energy-rich Amphipoda are consumed during winter and krill during summer [13]. Our data support the importance of krill and amphipods in the diet of all examined fish species. Literature data agree with diet variations depending on size (ontogenetic shift) and between different sampling sites. 


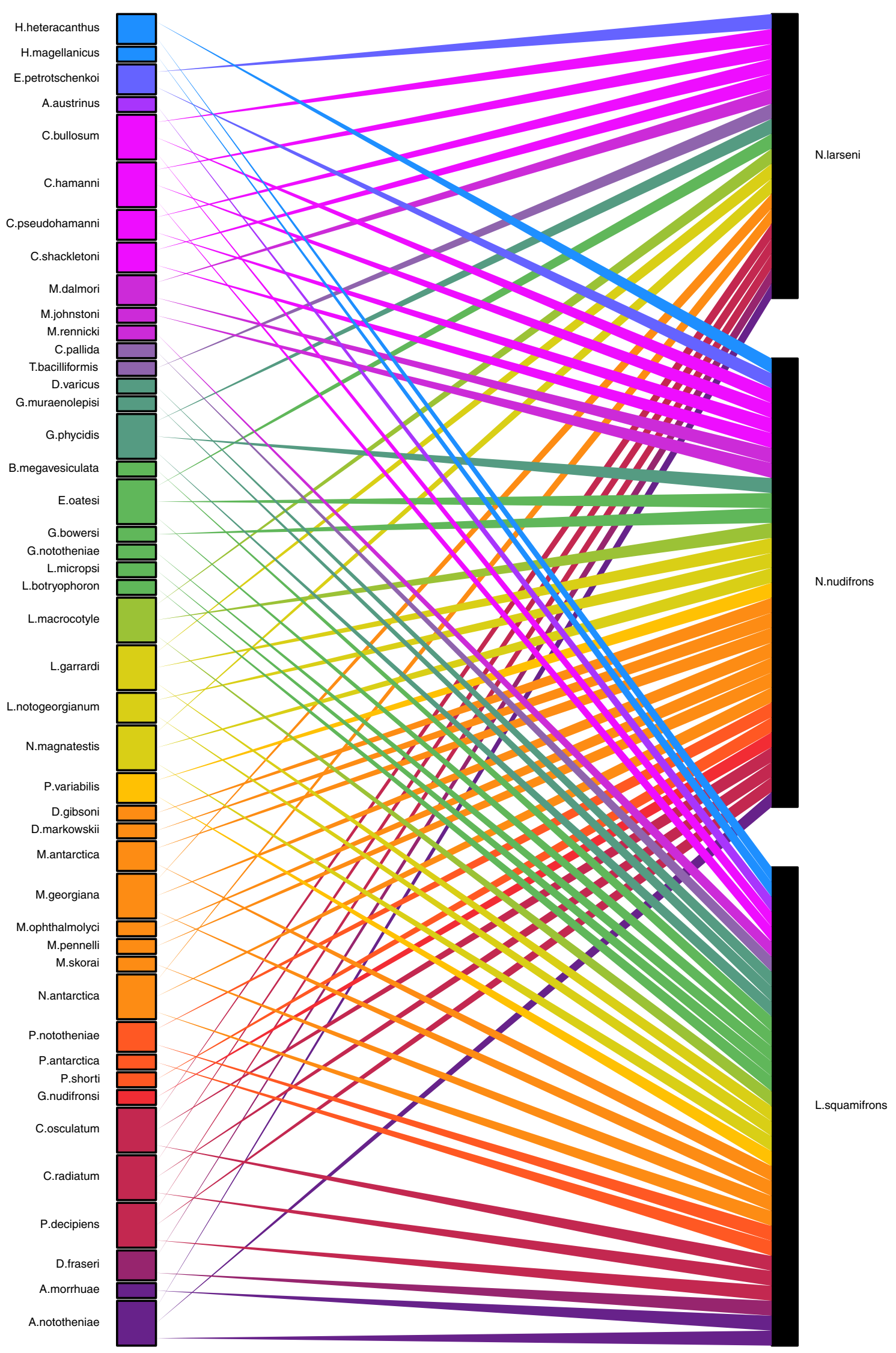


4Fig. 3 Reported parasites of Nototheniops larseni, N. nudfrons and Lepidonotothen squamifrons represented as bipartite network plot. Ray and box color indicates the parasite family, box size increases with the number of connections (colour figure online)

\section{Parasites of the Examined Nototheniinae}

\section{Digenea}

In our study, infections with Digenea were rare in Nototheniops larseni and $N$. nudifrons and more frequent in Lepidonotothen squamifrons. Most known digeneans found in the Southern Ocean infect fish hosts associated with a benthic habitat. An increase in infection intensity of fish hosts with digeneans, but a site effect with a decrease in taxon diversity has been described in coastal areas compared to offshore sites [29].

Elytrophalloides oatesi (Hemiuridae) is frequently detected in Antarctic fish (e.g. N. nudifrons) [31] but it is not endemic to the Southern Ocean [69] and the reported host range is wide $[37,69,70]$. It is not host-specific to Nototheniidae and it does not imply a restriction of the host to the Southern Ocean. Elytrophalloides oatesi could be considered an indicator of a benthopelagic fish host, the life cycle of Hemiuridae includes a pelagic intermediate host $[71,72]$. This is supported by our findings on the diet and parasitisation of L. squamifrons.

The general distribution and ecology of Lepidapedon garrardi (Lepocreadiidae) is similar to E. oatesi, as it occurs in Notothenioidei and is found throughout the Southern Ocean and Sub-Antarctic regions [29, 70]. The genus includes 30 species $[72,73]$. In contrast to our findings, L. garrardi was the dominant digenean of Nototheniops nudifrons at Admiralty Bay, occurring with high intensities to 131 parasites per host [31]. This difference could be owed to a site effect between King George Island and Elephant Island. This effect had been described for L. garrardi infection of T. bernacchii, which could also apply to L. garrardi and $N$. nudifrons in this study [74].

Neolebouria antarctica (Opecoelidae) was detected in all host species examined in this study and is frequently found in Notothenioidei and Liparididae (Table S4, [29]). Its distribution covers West Antarctica and South Georgia, while its congener $N$. terranovensis is found in East Antarctica (Weddell and Ross Sea, Indian Sector) [29]. The life cycle of $N$. antarctica includes a metacercariae stage in crustaceans [70, 75], which could play an important role in the transmission to fishes. Its infection parameters seem to vary with site and host species. The low prevalence in $N$. nudifrons detected in this study agrees with findings from Laskowski \& Zdzitowiecki [31] from Vernadsky Station (Argentine Islands, Antarctic Peninsula).
The aforementioned Digenea have all been previously detected in the examined host species (Table S3), except Lepidapedon garrardi in Lepidonotothen squamifrons, for which we provided a new host record.

\section{Nematoda}

Nematodes were the most prevalent and numerous parasites of the examined Nototheniidae. The nematode infection of the examined fishes is connected to their demersal lifestyle. The similarities of the euryxenous parasites of the three host species are also reflected within this group, including larval stages of the anisakids Pseudoterranova decipiens (s.1.) and Contracaecum osculatum (s.1.). Considering that we molecularly identified a subsample as Pseudoterranova decipiens $\mathrm{E}$, which is the only species from the $P$. decipiens complex occurring in Antarctic fishes [76], it can be assumed that the parasites identified as $P$. decipiens (s.1.) are most likely P. decipiens E. This species has been reported to be characteristic of the lower Antarctic shelves of the seasonal pack ice zone [77]. Pseudoterranova decipiens E requires a pinniped definitive host, specifically the Weddell Seal (Leptonychotes weddellii) $[76,78]$. The occurrence of $P$. decipiens $\mathrm{E}$ is limited by depth, they are found at the shallow shelf, because deep waters are not frequented by hunting Weddell seals [77]. Pseudoterranova decipiens $\mathrm{E}$ is restricted to benthic or benthopelagic fish hosts, it does not occur in pelagic fishes [77, 79]. Most seal species hunt in the water column [10, $80,81]$ but isotopic analyses by Burns et al. [82] showed that Leptonychotes weddellii also consumes benthic prey. A more recent study by Daneri et al. [83] analysed the fish prey of $L$. weddellii at Hope Bay and showed that its main food were Nototheniidae (80\%). Nototheniops larseni seemed to be an important food item (normalised IRI $=13.9 \%$ ), while $N$. nudifrons and Lepidonotothen squamifrons were rarer prey of Leptonychotes weddellii [83]. The parasitological data from our study suggest that all examined fish hosts contribute to the transmission of $P$. decipiens $\mathrm{E}$ to its definitive host at the respective sampling site.

Contracaecum osculatum (s.1.) also uses seals as definitive host. Co-infections of the fish host, as observed in this study, are common, and suggestions of Contracaecum spp. outcompeting Pseudoterranova spp. in the definitive hosts have been questioned [25]. Similar to Pseudoterranova decipiens $\mathrm{E}$, the life cycle of Contracaecum osculatum involves demersal intermediate hosts, while its congener C. radiatum (not detected in this study) is found in pelagic intermediate hosts [84].

Since anisakid nematodes tend to be less specific regarding paratenic fish hosts [85], they have been 


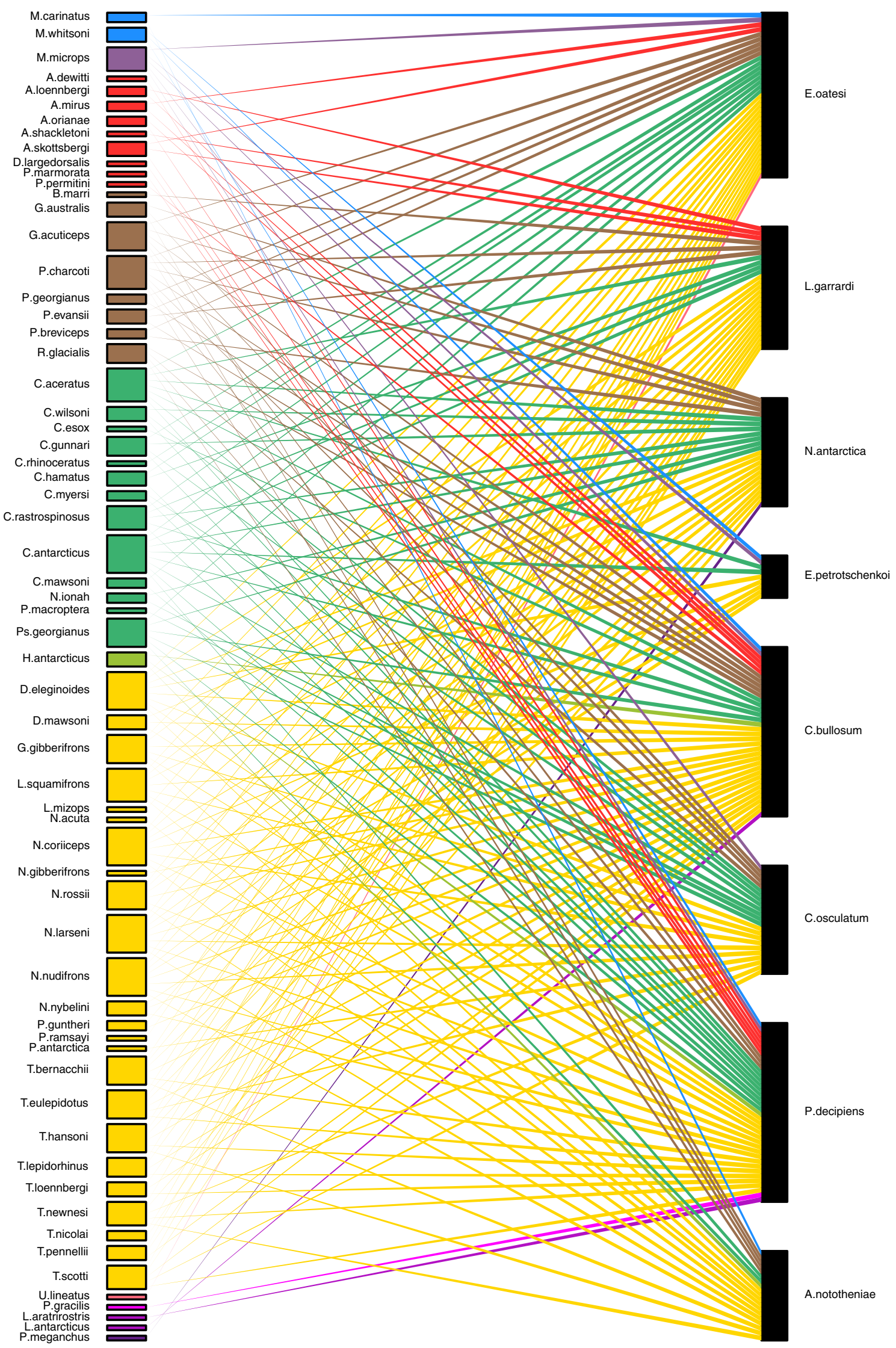


4Fig. 4 Reported host spectrum of the parasites of Nototheniops larseni, $N$. nudifrons and Lepidonotothen squmaifrons detected in this study represented as a bipartite network plot. Ray and box color indicates the host family, box size increases with the number of connections (colour figure online)

recorded in a wide range of hosts from the Southern Ocean.

The cystidicolid nematode Ascarophis nototheniae was only detected in $N$. nudifrons in this study. It is one of six Antarctic nematodes maturing in fish and is common in Notothenioidei, especially Nototheniidae [86]. Ascarophis spp. have been described to use Decapoda as their intermediate host [87]. This indicates that $N$. nudifrons infected by A. nototheniae have been feeding on its reported benthic shrimp hosts, such as Chorismus antarcticus and Notocrangon antarcticus [88].

\section{Acanthocephala}

Acanthocephala were abundant parasites of the examined fish species. While Corynosoma spp. were more frequent in Nototheniops nudifrons and Lepidonotothen squmaifrons, Metacanthocephalus spp. were more prevalent in N. nudifrons. The detection of $E$. petrotschenkoi in two specimens of $N$. larseni represents a new host record.

All Acanthocephala maturing in Antarctic fish have two hosts within their life cycle, if the definitive hosts are birds or seals, their life cycle includes three hosts [42, 70]. Antarctic acanthocephalans are frequent in demersal fish hosts and absent in fishes with a pelagic lifestyle, which suggests a benthic intermediate host and a bottom-feeding definitive host $[42,70]$. Some Acanthocephala are typical for the region south of the ACC (lower Antarctica), Metacanthocephalus johnstoni, M. dalmori, Aspersentis megarhynchus, Echinorhinchus petrotschenkoi, E. muranolepis, Corynosoma bullosum, C. arctocephali, C. hamanni, C. shackletoni [70]. Most Acanthocephala found in the Southern Ocean are more common in coastal habitats and fish hosts acquire the parasite if they are associated to this habitat permanently or during specific life-history events, e.g. spawning [28].

The life cycle of Corynosoma spp. at the South Shetland Islands (Admiralty Bay) involves Amphipoda as intermediate hosts [89]. Cystacanths of Corynosoma hamanni and C. pseudohamanni were detected in Prostibbingia brevicornis and Cheirimedon femoratus, Corynosoma bullosum occurred in Waldeckia obesa and Bovallia gigantea [89]. Corynosoma spp. have a wide range of teleost hosts ([90], Table S4). Corynosoma bullosum is specific to its definitive host, the Southern Sea Elephant Mirounga leonina [77, 91], occurring at the lower latitudes of Antarctica, around the Antarctic Peninsula, SSI and Sub-Antarctica [92]. The definitive hosts of Corynosoma pseudohamanni, Crabeater
Seals and Weddell Seals, only occur in higher Antarctica [93]. The reported abundance of $C$. bullosum at shelf and offshore sites matches our findings at shelf sampling sites around Elephant Island. Corynosoma pseudohamanni and C. hamanni rarely occur in fishes from shelf areas [28]. The infection of Nototheniops larseni and N. nudifrons and Lepidonotothen squamifrons with Corynosoma spp. points to a trophic connection as prey of pinnipeds.

The definitive hosts of Metacanthocephalus spp. (Rhadinorhynchidae) are fish [94, 95]. The genus occurs in 2-3 families belonging to the Notothenioidei [42, 70]. Metacanthocephalus johnstoni occurs in Cheirimedon femoratus, while M. dalmori has been found in deeper living Crustacean hosts, indicating different depth ranges [94]. Zdzitowiecki and Laskowski [96] reported that the infection intensity of $N$. nudifrons with Acanthocephala had increased compared to findings from 1978/1979. Similar to our findings, Rhadinorhynchida (Metacanthocephalus spp.) were more numerous in N. nudifrons than Polymorphida (Corynosoma spp.) [96].

Echinorhynchus spp. are known as parasites of gadiform fishes [28]. Echinorhynchus petrotschenkoi occurs in the Antarctic species from this taxonomic order, Muraenolepis microps and M. whitsoni (Macrouridae), but has also been reported in various Nototheniidae, e.g. Nototheniops nudifrons [28, 70, 97]. A connection between the infection intensity of Echinorhynchus sp. in nototheniids to the diversity of Crustacea in their habitat has been shown [74]. The prevalence of Echinorhynchus spp. is unusual in fjords and near shore habitats [28], the infection of $N$. larseni was acquired from an intermediate host at an offshore site and could be an indicator for migrations.

\section{Parasite Specificity}

A common feature of all parasites infecting hosts from the present study is their low host specificity regarding the teleost host. All parasites have a host spectrum including more than one taxonomic family, qualifying as 'euryxenous' [98]. Most hosts belong to the suborder Notothenioidei and the family Nototheniidae, which constitute the largest proportion of Antarctic fish diversity. Rohde and Heap [99] stated that the parasite fauna of one Antarctic fish species could be dominated by different parasite taxa, resulting in individualspecific parasitisation patterns.

Including previous records on the parasite fauna of the three species examined in this study (see Table S3), there seems to be a connection with parasite diversity and sampling effort (number of host species and number of sampling sites) but also host size, since the larger species Lepidonotothen squamifrons has a lot more parasite records than the smaller species Nototheniops larseni, which has also been less studied. The parasite diversity reported in $L$. squamifrons is probably owed to a higher trophic level and a 
sampling bias in favour of larger fish species. The parasite fauna of the Southern Ocean's largest teleosts, Dissostichus spp., is well studied due to commercial interest in these species as a fishery resource [32]. Possibly due to the top position in the food web and also a larger number of studies, a large number of parasites have been described for Dissostichus spp. (357 entries in Oğuz et al. [37]).

Observations of site effects on parasite patterns in Antarctic Nototheniidae have been made in previous studies. A site variability of infection patterns with Digenea and Acanthocephala has previously been described for $N$. nudifrons [31] and other Nototheniids [100] and could explain observations made in this study. Laskowski \& Zdzitowiecki [31] found a site effect comparing the infection of $N$. nudifrons with the digeneans Lepidapedon garrardi, Elytrophalloides oatesi and Neolebouria antarctica. Also, the infection with the acantocephalan Corynosoma pseudohamanni varied between sites. This suggests that these parasites might use different macroinvertebrate hosts that thrive differently at the respective sampling sites. Opportunistic food choice and adaptation to different feeding strategies of the fish hosts resulting from the structural features (rocky, sandy, slope) of a site could also result in varying infection intensities between studies. Studies by Moser and Cowen [74] and Münster et al. [101] observed site effects in the parasite communities of Trematomus bernacchii and Macrourus whitsoni. The design of future studies using fish parasite communities as indicators of ecosystem changes needs to account for site effects.

\section{Conclusion}

Polar ecosystems are currently subject to the serious effects of climate change. Parasite communities and their patterns and distributions in particular can be used for the management of Antarctic marine resources and the monitoring of climate change effects on biotic communities. However, biomonitoring of parasite communities in model host species should take into account potential site effects on infection numbers. Thus, despite the challenges and limited opportunities for fishing in these remote areas, biomonitoring must ideally be carried out periodically in a predefined range of habitats and sites, including as many levels as possible, to be able to track, compare, and better understand changes in the future.

Supplementary Information The online version contains supplementary material available at https://doi.org/10.1007/s11686-021-00455-8.

Acknowledgements The authors are grateful to all participants of the ANT-XXVIII/4 expedition of the RV Polarstern. We thank Jan N. Zaabe who examined the fish samples and Birgit Nagel and Gabriele Elter for their contribution to the laboratory work.
Author contributions KGA, SC, JK and SK conceived of the study and wrote the manuscript. KGA carried out the analysis and SC created the figures. JK revised the manuscript.

Funding Open Access funding enabled and organized by Projekt DEAL. Not applicable.

\section{Declarations}

Conflict of interest The authors declare they do not have competing interests.

Ethics approval Approval of our present study by a review board institution or ethics committee was not necessary because all fish were caught during a regular research cruise onboard the RV Polarstern. No living animals were used. All fish were expertly killed according to the German Animal Protection Law (§4) and the ordinance of slaughter and killing of animals (Tierschlachtverordnung § 13).

Consent to participate Not applicable.

Consent for publication All authors gave final approval for publication and agree to be held accountable for the work performed therein.

Open Access This article is licensed under a Creative Commons Attribution 4.0 International License, which permits use, sharing, adaptation, distribution and reproduction in any medium or format, as long as you give appropriate credit to the original author(s) and the source, provide a link to the Creative Commons licence, and indicate if changes were made. The images or other third party material in this article are included in the article's Creative Commons licence, unless indicated otherwise in a credit line to the material. If material is not included in the article's Creative Commons licence and your intended use is not permitted by statutory regulation or exceeds the permitted use, you will need to obtain permission directly from the copyright holder. To view a copy of this licence, visit http://creativecommons.org/licenses/by/4.0/.

\section{References}

1. Orsi AH, Whitworth T, Nowlin WD (1995) On the meridional extent and fronts of the Antarctic Circumpolar Current. Deep Sea Res Part I 42:641-673. https://doi.org/10.1016/0967-0637(95) 00021-W

2. Kock K-H (1992) Antarctic fish and fisheries. Cambridge University Press, Cambridge

3. Rogers AD, Tyler PA, Connelly DP, Copley JT, James R, Larter RD, Linse K, Mills RA, Garabato AN, Pancost RD, Pearce DA, Polunin NVC, German CR, Shank T, Boersch-Supan PH, Alker BJ, Aquilina A, Bennett SA, Clarke A, Dinley RJJ, Graham AGC, Green DRH, Hawkes JA, Hepburn L, Hilario A, Huvenne VAI, Marsh L, Ramirez-Llodra E, Reid WDK, Roterman CN, Sweeting CJ, Thatje S, Zwirglmaier K (2012) The discovery of new deep-sea hydrothermal vent communities in the Southern Ocean and implications for biogeography. PLoS Biol 10:e1001234. https://doi.org/10.1371/journal.pbio.1001234

4. Foppert A, Donohue KA, Watts DR (2016) The polar front in drake passage: a composite-mean stream-coordinate view. J Geophys Res Oceans 121:1771-1788. https://doi.org/10.1002/2015J C011333

5. Atkinson A, Siegel V, Pakhomov E, Rothery P (2004) Long-term decline in krill stock and increase in salps within the Southern 
Ocean. Nature 432:100-103. https://doi.org/10.1038/natur e02996

6. Marr JWS (1962) The natural history and geography of the Antarctic krill (Euphausia superba Dana). Discovery Rep 32:33-464

7. Siegel V (2000) Krill (Euphausiacea) demography and variability in abundance and distribution. Can J Fish Aquat Sci 57:151-167. https://doi.org/10.1139/f00-184

8. Quetin LB, Ross RM (2003) Episodic recruitment in Antarctic krill Euphausia superba in the Palmer LTER study region. Mar Ecol Prog Ser 259:185-200. https://doi.org/10.3354/meps259185

9. Hofmann EE, Hüsrevoğlu YS (2003) A circumpolar modeling study of habitat control of Antarctic krill (Euphausia superba) reproductive success. Deep Sea Res Part II 50:3121-3142. https://doi.org/10.1016/j.dsr2.2003.07.012

10. Eastman JT (1993) Antarctic fish Biology_Evolution in a unique environment. Academic Press Inc, San Diego

11. Hahn-Woernle L, Powell B, Lundesgaard Ø, van Wessem M (2020) Sensitivity of the summer upper ocean heat content in a Western Antarctic Peninsula fjord. Prog Oceanogr 183:102287. https://doi.org/10.1016/j.pocean.2020.102287

12. Turner J, Marshall GJ, Clem K, Colwell S, Phillips T, Lu H (2020) Antarctic temperature variability and change from station data. Int J Climatol 40:2986-3007. https://doi.org/10.1002/joc. 6378

13. Barrera-Oro E (2002) The role of fish in the Antarctic marine food web: differences between inshore and offshore waters in the southern Scotia Arc and west Antarctic Peninsula. Antarct Sci 14:293-309. https://doi.org/10.1017/S0954102002000111

14. Eastman JT, Clarke A (1998) A comparison of adaptive radiations of Antarctic fish with those of NonAntarctic fish. In: Di Prisco G, Pisano E, Clarke A (eds) Fishes of Antarctica: a biological overview. Springer Milan, Milano, pp 3-26

15. Gon O, Heemstra PC (1990) Fishes of the Southern Ocean, 1st edn. J. L. B. Smith Institute of Ichthyology, Grahamstown

16. Near TJ, Pesavento JJ, Cheng C-HC (2004) Phylogenetic investigations of Antarctic notothenioid fishes (Perciformes: Notothenioidei) using complete gene sequences of the mitochondrial encoded 16S rRNA. Mol Phylogenet Evol 32:881-891. https:// doi.org/10.1016/j.ympev.2004.01.002

17. Eastman JT (2005) The nature of the diversity of Antarctic fishes. Polar Biol 28:93-107. https://doi.org/10.1007/ s00300-004-0667-4

18. Hewitt GC, Hine PM (1972) Checklist of parasites of New Zealand fishes and of their hosts. N Z J Mar Freshw Res 6:69-114. https://doi.org/10.1080/00288330.1977.9515410

19. Hine M, Jones JB, Diggles BK (2000) A checklist of the parasites of New Zealand fishes including previously unpublished records. The National Institute of Water and Atmospheric Research, Wellington

20. Grabda J, Ślósarczyk W (1981) Parasites of marine fishes from New Zealand. Acta Ichthyol Piscat XI:85-102

21. Kock K-H, Stransky C (2000) The composition of the coastal fish fauna around Elephant Island (South Shetland Islands, Antarctica). Polar Biol 23:825-832. https://doi.org/10.1007/s0030 00000159

22. Tiedtke JE, Kock K-H (1989) Structure and composition of the demersal fish fauna around Elephant Island. Arch Fisch 39:143-169

23. Busch MW, Kuhn T, Münster J, Klimpel S (2012) Marine crustaceans as potential hosts and vectors for metazoan parasites. In: Mehlhorn H (ed) Arthropods as vectors of emerging diseases. Springer, Berlin, pp 329-360

24. Marcogliese DJ (1995) The role of zooplankton in the transmission of helminth parasites to fish. Rev Fish Biol Fisheries 5:336-371. https://doi.org/10.1007/BF00043006
25. Marcogliese DJ (1996) Transmission of the sealworm, Pseudoterranova decipiens (Krabbe), from invertebrates to fish in an enclosed brackish pond. J Exp Mar Biol Ecol 205:205-219. https://doi.org/10.1016/S0022-0981(96)02613-5

26. Zdzitowiecki K, Pisano E, Vacchi M (1993) Antarctic representatives of the genus Neolebouria Gibson, 1976 (Digenea, Opecoelidae), with description of one new species. Acta Parasitol 38:11-14

27. Zdzitowiecki K (1988) Occurrence of digenetic trematodes in fishes off South Shetlands (Antarctic). Acta Parasitologica Polonica 33:155-167

28. Zdzitowiecki K (1990) Occurrence of acanthocephalans in fishes of the open sea off the South Shetlands and South Georgia (Antarctic). Acta Parasitologica Polonica 35:131-141

29. Zdzitowiecki K (1998) Diversity of Digenea, parasites of fishes in various areas of the Antarctic. In: Di Prisco G, Pisano E, Clarke A (eds) Fishes of Antarctica: a biological overview. Springer Milan, Milano, pp 87-94

30. Palm HW, Klimpel S, Walter T (2007) Demersal fish parasite fauna around the South Shetland Islands: high species richness and low host specificity in deep Antarctic waters. Polar Biol 30:1513-1522. https://doi.org/10.1007/s00300-007-0312-0

31. Laskowski Z, Zdzitowiecki K (2005) The helminth fauna of some notothenioid fishes collected from the shelf of Argentine Islands, West Antarctica. Pol Polar Res 26:315-324

32. Froese R, Pauly D (2021) FishBase. World wide web electronic publication. https://www.fishbase.org. Accessed 15 July 2021

33. WoRMS Editorial Board (2020) World register of marine species. WoRMS Editorial Board, Belgium

34. Fricke R, Eschmeyer, WN, an der Laan R (2021) Eschmeyer's catalog of fishes: Genera, species, references. http://researchar chive.calacademy.org/research/ichthyology/catalog/fishcatmain. asp. Accessed 15 July 2021

35. Near TJ, MacGuigan DJ, Parker E, Struthers CD, Jones CD, Dornburg A (2018) Phylogenetic analysis of Antarctic notothenioids illuminates the utility of RADseq for resolving Cenozoic adaptive radiations. Mol Phylogenet Evol 129:268-279. https:// doi.org/10.1016/j.ympev.2018.09.001

36. Miya T, Gon O, Mwale M, Poulin E (2016) Molecular systematics and taxonomic status of three latitudinally widespread nototheniid (Perciformes: Notothenioidei) fishes from the Southern Ocean. Zootaxa 4061:381-396. https://doi.org/10.11646/zoota xa.4061.4.4

37. Oğuz MC, Tepe Y, Belk MC, Heckmann RA, Aslan B, Gürgen M, Bray RA, Akgül Ü (2015) Metazoan parasites of Antarctic fishes. Turkiye parazitolojii dergisi. https://doi.org/10.5152/tpd. 2015.3661

38. Gibson DI, Bray RA, Harris EA (2005). Host-parasite database of the natural history museum, London. https://www.nhm.ac.uk/ research-curation/scientific-resources/taxonomy-systematics/ host-parasites/. Accessed 15 July 2021

39. Brandl SJ, Casey JM, Meyer CP (2020) Dietary and habitat niche partitioning in congeneric cryptobenthic reef fish species. Coral Reefs 39:305-317. https://doi.org/10.1007/s00338-020-01892-z

40. Hyslop EJ (1980) Stomach contents analysis - a review of methods and their application. J Fish Biol 17:411-429. https://doi.org/ 10.1111/j.1095-8649.1980.tb02775.x

41. Bush AO, Lafferty KD, Lotz JM, Shostak AW (1997) Parasitology meets ecology on its own terms: Margolis et al. revisited. J Parasitol 83:575. https://doi.org/10.2307/3284227

42. Zdzitowiecki K (1991) Antarctic Acanthocephala. Koeltz Scientific Books, Königstein

43. Zdzitowiecki K (1997) Antarctic digenea parasites of fishes. Koeltz Scientific Books, Königstein 
44. Klimpel S, Kleinertz S, Hanel R, Rückert S (2007) Genetic variability in Hysterothylacium aduncum, a raphidascarid nematode isolated from sprat (Sprattus sprattus) of different geographical areas of the northeastern Atlantic. Parasitol Res 101:1425-1430. https://doi.org/10.1007/s00436-007-0662-0

45. Zhu X, Gasser RB, Jacobs DE, Hung G-C, Chilton NB (2000) Relationships among some ascaridoid nematodes based on ribosomal DNA sequence data. Parasitol Res 86:738-744. https:// doi.org/10.1007/PL00008561

46. Zhu X, Gasser RB, Podolska M, Chilton NB (1998) Characterisation of anisakid nematodes with zoonotic potential by nuclear ribosomal DNA sequences. Int J Parasitol 28:1911-1921. https:// doi.org/10.1016/S0020-7519(98)00150-7

47. Shih H-H (2004) Parasitic helminth fauna of the cutlass fish, Trichiurus lepturus L., and the differentiation of four anisakid nematode third-stage larvae by nuclear ribosomal DNA sequences. Parasitol Res. https://doi.org/10.1007/ s00436-004-1095-7

48. Altschul SF, Gish W, Miller W, Myers EW, Lipman DJ (1990) Basic local alignment search tool. J Mol Biol 215:403-410. https://doi.org/10.1016/S0022-2836(05)80360-2

49. Richardson MG (1975) The dietary composition of some Antarctic fish. Br Antarct Surv Bull 41:113-120

50. Targett TE (1981) Trophic ecology and structure of coastal Antarctic fish communities. Mar Ecol Prog Ser 4:243-263

51. Curcio N, Tombari A, Capitano F (2014) Otolith morphology and feeding ecology of an Antarctic nototheniid, Lepidonotothen larseni. Antarct Sci 26:124-132. https://doi.org/10.1017/S0954 102013000394

52. Blasina G, Cazorla AL, Antoni MD, Bruno D, Delpiani M, de Astarloa JMD (2017) Ontogenetic changes in the feeding strategy of Lepidonotothen nudifrons (Pisces, Nototheniidae) off the South Shetland Islands and the Antarctic Peninsula. Polar Res 36:1331558. https://doi.org/10.1080/17518369.2017.1331558

53. Deli Antoni MY, Delpiani SM, González-Castro M, Blasina GE, Spath MC, Depiani GE, Ashikaga FY, Cruz VP, Oliveira C, de Astarloa JMD (2019) Comparative populational study of Lepidonotothen larseni and L. nudifrons (Teleostei: Nototheniidae) from the Antarctic Peninsula and the South Shetland Islands. Antarctica Polar Biol 42:1537-1547. https://doi.org/10.1007/ s00300-019-02540-1

54. Casaux R, Barrera-Oro E, Baroni A, Ramón A (2003) Ecology of inshore notothenioid fish from the Danco Coast, Antarctic Peninsula. Polar Biol 26:157-165. https://doi.org/10.1007/ s00300-002-0463-y

55. Moreira E, Juares M, Barrera-Oro E (2014) Dietary overlap among early juvenile stages in an Antarctic notothenioid fish assemblage at Potter Cove, South Shetland Islands. Polar Biol 37:1507-1515. https://doi.org/10.1007/s00300-014-1545-3

56. Calbet A, Alcaraz M, Atienza D, Broglio E, Vaqué D (2005) Zooplankton biomass distribution patterns along the western Antarctic Peninsula (December 2002). J Plankton Res 27:1195-1203. https://doi.org/10.1093/plankt/fbi081

57. Lörz A-N, Brandt A (2003) Diversity of Peracarida (Crustacea, Malacostraca) caught in a suprabenthic sampler. Antarct Sci 15:433-438. https://doi.org/10.1017/S0954102003001536

58. Linse K, Brandt A, Hilbig B, Wegener G (2002) Composition and distribution of suprabenthic fauna in the south-eastern Weddell Sea and off King George Island. Antarct Sci 14:3-10. https://doi. org/10.1017/S0954102002000512

59. San Vicente C, Munilla T, Corbera J, Sorbe J-C, Ramos A (2009) Suprabenthic fauna from the Bellingshausen Sea and western Antarctic Peninsula: spatial distribution and community structure. Sci Mar 73:357-368. https://doi.org/10.3989/scimar.2009. $73 \mathrm{n} 2357$
60. Kellermann A (1990) Food and feeding dynamics of the larval Antarctic fish Nototheniops larseni. Mar Biol 106:159-167. https://doi.org/10.1007/BF01314796

61. Takahashi M, Iwami T (1997) The summer diet of demersal fish at the South Shetland Islands. Antarct Sci 9:407-413. https://doi. org/10.1017/S0954102097000527

62. Loeb V, Siegel V, Holm-Hansen O, Hewitt R, Fraser W, Trivelpiece W, Trivelpiece S (1997) Effects of sea-ice extent and krill or salp dominance on the Antarctic food web. Nature 387:897900. https://doi.org/10.1038/43174

63. Pakhomov EA, Froneman PW, Perissinotto R (2002) Salp/krill interactions in the Southern Ocean: spatial segregation and implications for the carbon flux. Deep Sea Res Part II 49:1881-1907. https://doi.org/10.1016/S0967-0645(02)00017-6

64. Perissinotto R, Pakhomov AE (1998) The trophic role of the tunicate Salpa thompsoni in the Antarctic marine ecosystem. J Mar Syst 17:361-374. https://doi.org/10.1016/S0924-7963(98) 00049-9

65. Gutt J, Siegel V (1994) Benthopelagic aggregations of krill (Euphausia superba) on the deeper shelf of the Weddell Sea (Antarctic). Deep Sea Res Part I 41:169-178. https://doi.org/10. 1016/0967-0637(94)90031-0

66. Kawaguchi K, Matsuda O, Ishikawa S, Naito Y (1986) A light trap to collect krill and other micronektonic and planktonic animals under the Antarctic coastal fast ice. Polar Biol 6:37-42. https://doi.org/10.1007/BF00446238

67. Kock K-H (1985) Krill consumption by Antarctic notothenioid fish. In: Siegfried WR, Condy PR, Laws RM (eds) Antarctic nutrient cycles and food webs. Springer, Berlin, pp 437-444

68. Marin VH, Brinton E, Huntley M (1991) Depth relationships of Euphausia superba eggs, larvae and adults near the Antarctic Peninsula, 1986-87. Deep Sea Res Part A Oceanogr Res Papers 38:1241-1249. https://doi.org/10.1016/0198-0149(91)90104-N

69. Jeżewski W, Zdzitowiecki K, Laskowski Z (2014) Digenea in notothenioid fish in the Beagle Channel (Magellanic subregion, sub-Antarctica). Acta Parasitol 59:42-49. https://doi. org/10.2478/s11686-014-0208-4

70. Rocka A (2006) Helminths of Antarctic fishes: Life cycle biology, specificity and geographical distribution. Acta Parasitol 51:26-35. https://doi.org/10.2478/s11686-006-0003-y

71. Campbell RA (1983) Parasitism in the deep sea. In: Rowe G (ed) The Sea. Deep-sea biology. Wiley, New York, pp 473-552

72. Walter T, Palm H, Piepiorka S, Rückert S (2002) Parasites of the Antarctic rattail Macrourus whitsoni (Regan, 1913) (Macrouridae, Gadiformes). Polar Biol 25:633-640. https://doi.org/ 10.1007/s00300-002-0407-6

73. Bray RA, Gibson DI (1990) The Lepocreadiidae (Digenea) of fishes of the North-East Atlantic-Review of the genera Opechona Looss, 1907 and Prodistomum Linton, 1910. Syst Parasitol 15:159-202. https://doi.org/10.1007/BF00010135

74. Moser M, Cowen RK (1991) The effects of periodic eutrophication on parasitism and stock identification of Trematomus bernacchii (Pisces: Nototheniidae) in McMurdo Sound, Antarctica. J Parasitol 77:551-556. https://doi.org/10.2307/32831 58

75. Gaevskaya AV (1982) The discovering of the trematode metacercarias in mysids of the South Georgia Island. Nauchnye Doklady Vysshey Shkoly, Biologicheskie Nauki 8:27-29

76. Palm HW (1999) Ecology of Pseudoterranova decipiens (Krabbe, 1878) (Nematoda: Anisakidae) from Antarctic waters. Parasitol Res 85:638-646. https://doi.org/10.1007/s004360050 608

77. Rocka A (2004) Nematodes of the Antarctic fishes. Pol Polar Res 25:135-152

78. McClelland G (2002) The trouble with sealworms (Pseudoterranova decipiens species complex, Nematoda): a review. 
Parasitology 124:183-203. https://doi.org/10.1017/S003118200 2001658

79. Bartsch A (1985) (in German) Comparative examinations of the parasite infection of Pleuragramma antarcticum and Trematomus scotti (Pisces: Nototheniidae) from eastern and southern Weddell Sea (Antarctica). Diploma Thesis, University of Bochum

80. Cherel Y, Koubbi P, Giraldo C, Penot F, Tavernier E, Moteki M, Ozouf-Costaz C, Causse R, Chartier A, Hosie G (2011) Isotopic niches of fishes in coastal, neritic and oceanic waters off Adélie land, Antarctica. Polar Sci 5:286-297. https://doi.org/10.1016/j. polar.2010.12.004

81. La Mesa M, Eastman JT, Vacchi M (2004) The role of notothenioid fish in the food web of the Ross Sea shelf waters: a review. Polar Biol 27:321-338. https://doi.org/10.1007/ s00300-004-0599-z

82. Burns JM, Trumble SJ, Castellini MA, Testa JW (1998) The diet of Weddell seals in McMurdo Sound, Antarctica as determined from scat collections and stable isotope analysis. Polar Biol 19:272-282. https://doi.org/10.1007/s003000050245

83. Daneri GA, Negri A, Coria NR, Negrete J, Libertelli MM, Corbalán A (2018) Fish prey of Weddell seals, Leptonychotes weddellii, at Hope Bay, Antarctic Peninsula, during the late summer. Polar Biol 41:1027-1031. https://doi.org/10.1007/s00300-018-2255-z

84. Klöser H, Plötz J, Palm H, Bartsch A, Hubold G (1992) Adjustment of anisakid nematode life cycles to the high Antarctic food web as shown by Contracaecum radiatum and C. osculatum in the Weddell Sea. Antarct Sci 4:171-178

85. Klimpel S, Busch MW, Sutton T, Palm HW (2010) Meso- and bathy-pelagic fish parasites at the Mid-Atlantic Ridge (MAR): low host specificity and restricted parasite diversity. Deep Sea Res Part I 57:596-603. https://doi.org/10.1016/j.dsr.2010.01.002

86. Rocka A (2017) Cestodes and nematodes of Antarctic fishes and birds. In: Klimpel S, Kuhn T, Mehlhorn H (eds) Biodiversity and evolution of parasitic life in the Southern Ocean. Springer International Publishing, Cham, pp 77-107

87. Holloway HL, Spence JA (1980) Ecology of animal parasites in McMurdo Sound, Antarctica. Comp Physiol Ecol 5:262-284

88. Dambach J, Thatje S, Rödder D, Basher Z, Raupach MJ (2012) Effects of late-cenozoic glaciation on habitat availability in Antarctic benthic shrimps (Crustacea: Decapoda: Caridea). PLoS ONE 7:e46283. https://doi.org/10.1371/journal.pone.0046283

89. Zdzitowiecki K, Presler P (2001) Occurrence of Acanthocephala in intermediate hosts, Amphipoda, in Admiralty Bay, South Shetland Islands, Antarctica. Pol Polar Res 22:205-212

90. Münster J, Kochmann J, Grigat J, Klimpel S, Kuhn T (2017) Parasite fauna of the Antarctic dragonfish Parachaenichthys charcoti (Perciformes: Bathydraconidae) and closely related Bathydraconidae from the Antarctic Peninsula. Southern Ocean Parasites Vectors 10:235. https://doi.org/10.1186/s13071-017-2176-7
91. Zdzitowiecki K (1996) Acanthocephala in fish in the Weddell Sea (Antarctic). Acta Parasitol 41:199-203

92. Aznar FJ, de León GP-P, Raga JA (2006) Status of Corynosoma (Acanthocephala: Polymorphidae) based on anatomical, ecologi$\mathrm{cal}$, and phylogenetic evidence, with the erection of Pseudocorynosoma n. gen. para. J Parasitol 92:548-564. https://doi.org/ 10.1645/GE-715R.1

93. Zdzitowiecki K (1984) Redescription of Corynosoma hamanni (Linstow, 1892) and description of C. pseudohammi sp. n. (Acanthocephala) from the environs of the South Shetlands (Antarctic). Acta Parasitologica Polonica 29:379-393

94. Laskowski Z, Zdzitowiecki K (2010) Contribution to the knowledge of the infection with Acanthocephala of a predatory Antarctic ice-fish Chaenocephalus aceratus. Pol Polar Res 31:303-308. https://doi.org/10.2478/v10183-010-0007-z

95. Zdzitowiecki K (1983) Antarctic acanthocephalans of the genus Metacanthocephalus. Acta Parasitologica Polonica 28:38-52

96. Zdzitowiecki K, Laskowski Z (2013) New data on the occurrence of Acanthocephala in some fish in Admiralty Bay (South Shetland Islands). Acta Parasit 58:547-550. https://doi.org/10. 2478/s11686-013-0175-1

97. Zdzitowiecki K, White MG (1992) Acanthocephalan infection of inshore fish in two fjords at South Georgia. Antarct Sci 4:197203. https://doi.org/10.1017/S0954102092000300

98. Palm HW, Caira JN (2008) Host specificity of adult versus larval cestodes of the elasmobranch tapeworm order Trypanorhyncha. Int J Parasitol 38:381-388. https://doi.org/10.1016/j.ijpara.2007. 08.011

99. Rohde K, Heap M (1998) Latitudinal differences in species and community richness and in community structure of metazoan endo- and ectoparasites of marine teleost fish. Int J Parasitol 28:461-474. https://doi.org/10.1016/S0020-7519(97)00209-9

100. Muñoz G, Rebolledo M (2019) Comparison of the parasite community of two notothens, Notothenia rossii and $N$. coriiceps (Pisces: Nototheniidae), from King George Island. Antarctica J Helminthol 93:732-737. https://doi.org/10.1017/S0022149X1 8000858

101. Münster J, Kochmann J, Klimpel S, Klapper R, Kuhn T (2016) Parasite fauna of Antarctic Macrourus whitsoni (Gadiformes: Macrouridae) in comparison with closely related macrourids. Parasit Vectors 9:403. https://doi.org/10.1186/ s13071-016-1688-x

Publisher's Note Springer Nature remains neutral with regard to jurisdictional claims in published maps and institutional affiliations. 